\title{
Leprosy Resilience with Disabilities Due to IIIness: A Qualitative Study
}

Indonesian Nursing Journal of Education and Clinic (INJEC)

95- 106

Volume 5, Issue 2, December 2020

DOI: 10.24990/injec.v5i2.298

injec.aipni-ainec.org/index.php/INJEC/index

Received : 2020-05-17

Accepted : 2020-05-26

The Association of Indonesian Nurse

Education Center (AINEC)

\section{Atika Jatimi' $^{1}$, Ah $^{\text {Yusuf' }}{ }^{\circledR}$, Sestu Retno Dwi Andayani ${ }^{2}$}

\begin{abstract}
Introduction: Leprosy is an infectious disease that still causes complex problems. The problem in question is not only in medical and physical terms, such as disability, but extends to social, economic, and cultural problems. This study aims to explore the experience of leprosy sufferers with disabilities to achieve resilience.

Methods: A descriptive qualitative research design with a phenomenological approach was used. The number of participants was eleven people affected by leprosy with grade I and 2 disabilities in Sumenep Regency obtained by a purposive sampling technique. Data collection used in-depth interviews with interview guides and field notes; the results of data collection were analyzed with theme analysis.

Results: This study produced five main themes about the experience of leprosy patients in the process of achieving resilience, namely: I) self-stigma as a stressor experienced by person affected with leprosy, 2) psychosocial problems that arise in response to stressors, 3) active coping as a method of resolving stress, 4) positive adaptation as a form of self-adjustment, 5) characteristics of strong individuals.

Conclusion: Some consider the word "leper" offensive, preferring the phrase "person affected with leprosy. Person affected with leprosy with disabilities identify self-stigma as a stressor that triggers the emergence of psychosocial problems. Individuals can form tough characteristics, such as responding positively to unexpected conditions, becoming more productive, and showing helping others behavior after overcoming stressors through the stages of active coping and positive adaptation.
\end{abstract}

\section{Keywords}

adaptation; coping; disability; leprosy; resilience

\section{INTRODUCTION}

Individuals diagnosed with leprosy have many effects occurring, both physically and psychologically, causing emotional (Lusli et al., 20I5), and social pressure (Dadun et al., 20I7). The physical impact on individuals diagnosed with leprosy is a disability; this causes individuals to experience many negative treatments from their environment (Lusli et al., 20I5). A disability that occurs suddenly, not from birth or during the initial phase of development, will have a considerable psychological impact on individuals (Hendriani, 2016). The most dominant impact is the acceptance and support of the closest people and the community in regard to person affected with leprosy; the social impact of this

\footnotetext{
I Faculty of Nursing, Universitas Airlangga, Surabaya, Indonesia
}

2 STIKes Pemkab Jombang, Jombang, Indonesia

Corresponding Author:

Ah Yusuf, Faculty of Nursing, Universitas Airlangga, Surabaya, Indonesia

Universitas Airlangga Kampus C, Jl. Mulyorejo, Mulyorejo, Surabaya, Kota SBY, Jawa Timur 60II5

Email: ah-yusuf@fkp.unair.ac.id 
disease is so great that it causes profound unrest, not only to the client himself, but to his family, community, and country (Sodik, 20I6). Social impact is one of the aspects that underlies the concept of the client's acceptance of the disease, in which, for this condition, many patients still consider leprosy as contagious, untreatable, hereditary, God's curse, unclean and causes disability. This is a form of labeling and prejudice against leprosy and can affect the psychology of leprosy patients, who are the driving force for recovery (Grzybowski et al., 2016). On the other hand, discrimination that occurs in the community and is carried out by people closest to leprosy due to fear of contracting, is a trigger factor for stress (Nasrudin et al., 20l8).

This disease is spread throughout the world, with the main concentration in developing countries where hygiene and sanitation are not good. Indonesia is still the largest contributor to leprosy case, ranking number 3 in the world, after India and Brazil. The prevalence rate of leprosy in Indonesia in 2017 in 0.70 cases / 10,000 population and the number of new case discoveries is 6.08 cases per 100,000 population. In 2015-2017, the highest number of sufferers was in the province of East Java, which was 3,373 new leprosy case findings (Infodatin, 2018). East Java Province occupied the 7 th position at the national level in cases of people with leprosy disability level 2 per $1,000,000$ population in 2017 , but, in 2018 , the province of rose to 6th position (Kementrian Kesehatan RI, 2018) with the most significant contributor being the Sumenep district (Local Health Office of Sumenep Regency, 2017).

The response caused by stress sources is very diverse. It can be in the form of an adaptive response, that is the individual can bounce back from adversity caused by disability due to leprosy so that they can live normally and remain productive (Utami, 2017). According to Hendriani (2013, 2018), this ability can be defined as a normal stress response in the process of forming a person following the character of resilience. Resilience is the ability to bounce back, find meaning, and keep hoping and comes from a stimulus that arises from either the internal self or the environment. Individual resilience can be defined as ownership of the physical and economic resources needed to minimize disruption from an event. Resilience is the ability of individuals to rise again and adapt well in the face of difficulties, trauma, tragedy, threats, or even significant sources of stress (Southwick et al.,2016). Resilience is an adaptive capacity to respond to and recover from unexpected conditions (Lestari and Yusuf, 2017). Resilience provides the view of individuals with disabilities as complete people, who, even with their limitations, can continue to lead positive and meaningful lives (Sniatecki et al., 2019). Resilience is the best condition for the individual in the long process to achieve mental health. Person affected with leprosy with disabilities become more productive in daily life, showing the ability to assist others, being able to accept themselves as whole individuals, and show positive responses to any problems and conditions that are not expected to be indicators of the resilient individual characteristics (Hendriani, 2018). This study aims to explore the experience of leprosy sufferers with disabilities to achieve resilience.

\section{MATERIALS AND METHODS}

This study is a descriptive qualitative design with a phenomenological approach. Qualitative research is carried out to determine if a problem is found, starting from the existence of unique facts in the field (Yusuf et al., 2009). Participants in this study were eleven of thirty-one people affected by leprosy who have disabilities and were selected using purposive sampling - the interview method used face-to-face. Persons affected by leprosy must meet the following criteria: I) Participants were person affected with leprosy who have a disability because of their illness, 2) Participants were person affected with leprosy who have been resilient, measured using the Brief Resilience Scale (BRS) Questionnaire (Smith et al., 2008), 3) Cooperative participants during the research data collection process. 
Table I. Participant's Characteristics $(n=I I)$

\begin{tabular}{ccccccccc}
\hline Code & Age & Gender & $\begin{array}{c}\text { Level of } \\
\text { disability }\end{array}$ & Job & Education & $\begin{array}{c}\text { Long } \\
\text { treatment } \\
\text { program } \\
\text { (Month) }\end{array}$ & $\begin{array}{c}\text { Ethnic } \\
\text { group }\end{array}$ & Religion \\
\hline PI & 59 & M & 2 & Farmer & Primary School & 12 & Madurese & Islam \\
P2 & 48 & M & 2 & Trader & Primary School & 12 & Madurese & Islam \\
P3 & 27 & M & I & Farmer & Senior High School & 12 & Madurese & Islam \\
P4 & 28 & F & I & Entrepreneur & Junior High School & 12 & Madurese & Islam \\
P5 & 50 & F & 2 & Entrepreneur & Primary School & 12 & Madurese & Islam \\
P6 & 46 & F & 2 & Farmer & Primary School & 6 & Madurese & Islam \\
P7 & 36 & F & 2 & Farmer & Primary School & 6 & Madurese & Islam \\
P8 & 32 & F & I & Farmer & Primary School & 6 & Madurese & Islam \\
P9 & 34 & F & I & Farmer & Primary School & 6 & Madurese & Islam \\
PI0 & 48 & F & I & Farmer & Primary School & 12 & Madurese & Islam \\
PII & 28 & M & I & Trader & Senior High School & 12 & Madurese & Islam \\
\hline P: Patcinger
\end{tabular}

Table 2. Theme Distribution

\begin{tabular}{ll}
\hline \multicolumn{1}{c}{ Themes } & \multicolumn{1}{c}{ Sub-themes } \\
\hline Self-stigma & Labeling \\
Psychosocial problems & Discrimination \\
& Anxiety \\
& Withdrawal \\
& Self-concept disorders \\
Active coping & Utilizing social support \\
& Spirituality \\
Positive adaptations & Distraction techniques \\
& Active work \\
& Social interaction \\
& Adjustment of physical conditions \\
Characteristics of resilient individuals & Self-respect \\
& Responding positively to undesirable conditions \\
& Being more productive \\
& Helping others \\
\hline
\end{tabular}

This research was conducted in the working area of the Sumenep district health center in East Java within a period of two months, namely January-February 2020. Participants were visited at their respective homes by researchers for informed consent. Interviews were conducted after participants were willing to contribute to the research. The interview was conducted at each participant's home. The main instrument in this study is the researcher; the presence of researchers in data retrieval cannot be represented. Other instruments used in this study are voice recorders, field notes, and interview guidelines developed by researchers using semistructured interviews and which are more open-ended to bring up the views and opinions of the participants. The duration of the interview in each meeting was twenty-five minutes and conducted in two meetings. The first meeting was an explanation of the research, the signing of the informed consent, and an interview. The second meeting was filled with clarification of the results of the previous interview and the submission of unanswered questions. The data validity checking technique used is member checking by bringing back reports of specific themes in front of the participants to check whether they feel that the theme is accurate

Interview data were analyzed using thematic analysis and, research data analysis used a manual system because the vocabulary sorting used by participants had broad meanings and different meanings in each question. The following stages were occurred: I) Describe the phenomenon under study; 2) Collect a description of the phenomenon through the opinions or statements of participants; 3) Read the entire description of the phenomena that have been submitted by all participants; 4) Reread the transcripts of interviews and quote meaningful statements from all participants; 5) Describe the meaning 
of significant statements; 6) Organize a continuous collection into the theme group; 7) Write a complete description; 8) Meet the participants to validate the description of the analysis results; and 9) Combine the validation results data into analysis description, to be added to the final description. The study ethics were approved by the Airlangga University Faculty of Nursing Ethics Committee with the number 1866-KEPK.

\section{RESULTS}

Based on the age of the participants at the time of the interview it showed the majority were in the age range of 25-34 years, with most grade I disability and the duration of a 6month treatment program. The sex distribution of the participants was dominated by women, with the majority of the work of the participants being farmers. The majority of participants' education was elementary school graduates/equivalent, as many as eight (8) participants. Overall, participants were people of Madurese ethnicity (Table I).

The results of the study identified five themes, namely self-stigma, psychosocial problems, active coping, positive adaptation, and resilient individual characteristics. The first theme was selfstigma consisting of two sub-themes, namely labeling and discrimination. Psychosocial problems were the second theme, consisting of three sub-themes, namely anxiety, withdrawal, and selfconcept disorders. The third theme was active coping, which consists of three subthemes, namely utilizing social support, spirituality, and distraction techniques. The fourth theme was a positive adaptation. There were four sub-themes in the theme, namely active work, social interaction, adjustment of physical conditions, and selfrespect. The fifth theme was the characteristics of resilient individuals, consisting of three sub-themes, namely responding positively to undesirable conditions, being more productive, and helping others (Table 2).

\section{Theme I: Self-stigma}

Participants expressed their discomfort through various forms of attitudes and behaviors, implied from the participant's body language when interacting with family or researchers which stimulates the emergence of psychosocial problems. Psychosocial problems that arise in people with leprosy are anxiety characterized by feelings of fear and worry about changes in health conditions and having difficulty sleeping (Quotes 5-6). In addition to anxiety, patients also show withdrawal behavior from the community, which is characterized by more frequent silence in the house (Quotes 7-8). Withdrawal behavior is carried out by participants because they are ashamed of their physical disabilities (Quotes 9-10). (See the quotes in Table 3).

\section{Theme 2: Psychosocial problems}

The way participants express their discomfort with various forms of attitudes and behaviors, and implies from the participant's body language when interacting with family or researchers stimulates the emergence of psychosocial problems. Psychosocial problems that arise in people with leprosy are anxiety characterized by feelings of fear and worry about changes in health conditions and having difficulty sleeping (Quotes 5-6). In addition to anxiety, patients also show withdrawal behavior from the community, which is characterized by more frequent silence in the house (Quotes 7-8). Withdrawal behavior carried out by participants because they are ashamed of their physical disabilities (Quotes 9-10). (See the quotes in table 3). 
Table 3. Summary of Participants' Statements

\begin{tabular}{|c|c|}
\hline Quotes & Statements \\
\hline I. & $\begin{array}{l}\text { "Since leprosy, I stopped working in the city. I go home because I feel it's not the same as my friend." (P3) } \\
\text { (PII) }\end{array}$ \\
\hline 2. & "I feel a bit different when I'm with other people." (P4) (PI0) \\
\hline 3. & $\begin{array}{l}\text { "I began to reduce activities with people other than my family. I felt uncomfortable even though their attitudes } \\
\text { did not change." (P2) }\end{array}$ \\
\hline 4. & $\begin{array}{l}\text { "I feel very troublesome for my husband and family. Sometimes I feel sorry for my husband. Because, since I } \\
\text { have leprosy, I don't work and must be treated by my husband." (P8) }\end{array}$ \\
\hline 5. & "When I was first told that I had leprosy, I always felt afraid I would not recover from this disease." (P2) (P4) \\
\hline 6. & "I often have difficulty falling asleep at night, sometimes fearing that the disease will get worse." (R6) \\
\hline 7. & "I stopped participating in activities with my neighbors. I prefer to remain at home." (R9) \\
\hline 8. & "In addition to work I do not leave the house, I mostly sleep at home." (RII) \\
\hline 9. & "I am ashamed, feel unworthy when my body is full of disease, especially when someone visits" (R7) \\
\hline 10. & $\begin{array}{l}\text { "I feel ashamed, not confident to gather with neighbors after leprosy because my body's skin has turned black." } \\
\text { (RI0) }\end{array}$ \\
\hline II. & $\begin{array}{l}\text { "Thank God, the family supported me during the treatment, taking me to get medicine. The neighbors also } \\
\text { did not change their attitude; the officer also always visited me. Sometimes delivering drugs." (RI) }\end{array}$ \\
\hline 12. & $\begin{array}{l}\text { "My family accompanied me for treatment and reminded me to be obedient during the treatment program to } \\
\text { get better soon. Neighbors behave normally to me." (R2) }\end{array}$ \\
\hline 13. & "Every time I finish praying, I always ask that I get well soon." (R3) \\
\hline 14. & "I often ask God. Hopefully, I still have a chance to recover." (R4) \\
\hline 15. & $\begin{array}{l}\text { "If you want to go there for a long time. Cool, if you again harvest happier. Satisfied with your hard work, so } \\
\text { you don't have any other thoughts." (R9) }\end{array}$ \\
\hline 16. & $\begin{array}{l}\text { "Now I work in the garden, if I have a lot of thoughts I usually go to the fields. The air is fresh, lots of greenery. } \\
\text { I often calm down with activities in the garden." (RIO) }\end{array}$ \\
\hline 17. & $\begin{array}{l}\text { "Every day I sell bananas, I buy bananas from people in the garden and sell them to the market. While farming } \\
\text { in his field. Every day I go home healthy." (R2) }\end{array}$ \\
\hline 18. & $\begin{array}{l}\text { "Now, I work in the paddy fields of my father. The results are quite good. If the harvest is good, it can benefit } \\
\text { a lot. For three years I worked, the results were good every harvest, which was planted in all kinds. Rice, } \\
\text { corn, tobacco, and red onion." (R3) }\end{array}$ \\
\hline 19. & $\begin{array}{l}\text { "My family and I often gather at night. Especially if there are guests, usually until midnight, telling each other's } \\
\text { activities." (R7) }\end{array}$ \\
\hline 20. & $\begin{array}{l}\text { "My neighbors often invite me to tell stories, because, at first, I stayed more at home. Usually, we talk a lot } \\
\text { when we meet, like when we buy vegetables around the front of the house." (R8) }\end{array}$ \\
\hline 21. & "After recovering and completing treatment, I feel better. I'm comfortable when I'm active." (RI) \\
\hline 22. & "Right now, it's better. I can get back to normal activities. Even more diligent." (RII) \\
\hline 23. & "Now it's more accepting. It's not like it used to be." (R8) \\
\hline 24. & $\begin{array}{l}\text { "At first, I was sad with the condition of my body due to suffering from this disease, but now it is calmer." } \\
\text { (R9) }\end{array}$ \\
\hline 25. & $\begin{array}{l}\text { "From the break of dawn, I went to the rice fields, mowing the grass until 9pm. resting at home. In the } \\
\text { afternoon, I was in the fields again mowing the grass. I am capable of grazing cows with two heads of RT. } \\
\text { After a year, there will be profit sharing. If for every day I eat from the results of the farm." (RI) }\end{array}$ \\
\hline 26. & $\begin{array}{l}\text { "Every day, I can process palm water to be used as palm sugar. Get } 3 \mathrm{~kg} \text { a day. Then send my child to the } \\
\text { market to sell. Sometimes make mats from siwalan leaves. Then sold to the market." (R5) }\end{array}$ \\
\hline 27. & "I can deal with the problem calmly. Not rash, the point is already received. " (RI) \\
\hline 28. & "If there is something that is not what I want, it is not too angry or not shouting as before." (R2) \\
\hline 29. & $\begin{array}{l}\text { "Yes, even though I am handicapped, many neighbors still use my services to plant rice seeds in the fields. I } \\
\text { am also always willing." (R3) }\end{array}$ \\
\hline 30. & $\begin{array}{l}\text { "Initially, I was a person affected by leprosy. After that, my brother also had signs like phlegm. So, I will tell my } \\
\text { brother to check at the Health Primary Care, so he can immediately seek treatment." (R7) }\end{array}$ \\
\hline
\end{tabular}

\section{Theme 3: Active coping}

The way leprosy sufferers overcome psychosocial problems experienced is by utilizing psychosocial support, spirituality, and distraction techniques. Participants received social support when they had leprosy and could not encourage adherence to treatment. This showed that person affected with leprosy were able to use social support positively (Quotes I I-I 2 In addition to utilizing the social support of person affected with leprosy, they also pray diligently to God to ask for healing for their illness (Quotes 13-14) and try distraction techniques or seek distraction of the mind from stress by farming in the garden (Quotes 15-16). (See the quotes in Table 3). 


\section{Theme 4: Positive adaptations}

Participants described positive adaptation as adjusting to a good response to changes in current conditions. Different physical conditions do not become obstacles in every activity, both in working conditions (Quotes 17-18) or interacting with the community (Quotes 19-20). Participants explained that getting used to things is often done to be able to get rid of all feelings that refer to discomfort and despair (Quotes 2I-22) by respecting yourself and accepting changes in physical conditions (Quotes 23-24).

\section{Theme 5: Characteristics of resilient individuals}

Participants described resilience as the ability to accept changing health conditions and be able to take effective actions to overcome negative responses so that they can continue their daily activities without experiencing difficulties. Participants build resilient characteristics by forming adaptive behaviors, such as responding positively to undesirable circumstances (Quotes 27-28), becoming more productive by doing many activities in a physically disabled condition (Quotes 25-26), and being able to show their presence in the community by assisting others (Quotes 29-30).

\section{DISCUSSIONS}

Physical disability in people with leprosy becomes an individual psychological burden that triggers self-stigma, such as labeling and discrimination. Labeling and discrimination given by an individual against himself cause symptoms of anxiety with different intensity for each individual, withdrawal behavior that is characterized by avoiding interaction with others, and disruption of self-concept associated with problems of body image and self-esteem. Negative responses shown by individuals encourage them to overcome psychological burdens actively through the use of existing social support, increase spirituality in the components of gratitude, patience, and sincerity and shift the focus of their mind using the method of farming. After going through an active coping process, person affected with leprosy enter the stage of adaptation. This is shown by positive behaviors, such as being active at work, being able to interact with others, respecting themselves as whole individuals, and being able to adjust to changes in physical conditions due to leprosy. Positive behavior can shape the characteristics of resilient individuals, such as staying productive in everyday life, being able to accept oneself with all limitations and giving positive responses to any unexpected conditions.

The stressors described by the participants have a characteristic that is a disability as a complication of leprosy so as to cause self-stigma, such as labeling and discrimination against oneself. Leprosy is closely related to disability (Williams et al., 2019) caused by delayed treatment (Nardi Assis et al., 2019) due to lack of awareness and fear that is continually felt by individuals towards stigma and discrimination (Marfatia, Surani and Shah, 2020). Leprosy and disability are two terms that can trigger the emergence of stigma in the minds of individuals, so that when they are both encountered by the same person it can trigger a decrease in self-esteem and quality of life of individuals (Srinivas et al., 2019). Physical limitations experienced by person affected with leprosy form a psychological response by looking at themselves negatively.

Negative responses shown by leprosy patients trigger the emergence of self-stigma (Siddiqi, Chattopadhyay and Ghosh, 2017), which is a psychological stressor for person affected with leprosy, causing stress and depression (Utami, Haryanto and Sajidin, 2017). Psychological pressure on person affected with leprosy occurs due to decreased awareness and hope to help fight the stigma received (George, 2016). Stigma against oneself is an individual's perception that is felt by forms of discrimination. Discrimination against oneself on account of disability due to leprosy becomes an emotional burden that causes feelings of shame, low self-concept (Arachchi et al., 2017) and different feelings from others (GROOT, BRAKEL and VRIES DE, 2020). Persons affected by leprosy who experience limitations in their activities due to disability give a negative label to themselves as a depressive form that is characterized by feelings of discomfort when with other people, feeling unworthy of getting care from family and feeling different from others around them. 
Self-stigma committed by person affected with leprosy can trigger psychosocial problems. Psychosocial problems were exhibited by participants in the form of negative responses such as anxiety, withdrawal from the community, and self-concept disorders (Arifin, Kusnanto and Widyawati, 2020). The anxiety that appears to have most intensity is that diagnosed at the beginning of leprosy and undergoing treatment with symptoms of feeling worried and afraid of the disease getting worse, and difficulty in sleeping. Individuals with leprosy have emotional stress and anxiety (Farah Naaz et al., 2017). Anxiety often occurs in people with leprosy by showing tension, anger, and anxiety (Ramasamy et al., 2018). These symptoms arise as a result of psychological stress caused by disability after being diagnosed with leprosy (Barakat and Zaki, 2020). Emotional distress and anxiety can reduce individual independence (Yusuf, Suarilah and Rahmat, 20I0). Psychological pressure also causes other maladaptive behaviors shown by person affected with leprosy, such as lack of submission, feeling dissatisfied, depressed and hopeless, lack of physical activity or lack of movement, and often being alone (Rahmawati, Nafiah and Hidayati R, 20I5). Anxiety experienced by leprosy triggers other negative responses, such as withdrawal.

The behavior of withdrawing from the community is a form of self-defense mechanism to avoid the negative views of others around the house. The behavior is shown by leprosy sufferers by quitting a job they have maintained so far, not wanting to be visited by others when sick, rarely leaving the house, and preferring to remain at home to avoid interaction with others. Leprosy patients withdraw from their community after being diagnosed with leprosy (Richardus et al., 2018). The progress of leprosy is the biggest cause of withdrawal behavior (Zamparoni, 20I7). Many people with leprosy withdrawal do so to avoid the stigma of others outside the home (Borges and Machado, 2019). Withdrawal is also triggered by a decrease in self-concept after being diagnosed with leprosy and experiencing disability. Individual self-concept is influenced by various aspects, including body image and individual self-esteem. Body image is an individual assessment in looking at the current physical condition; people affected by leprosy with a disability have decreased confidence in their physical condition. Changes in physical conditions trigger symptoms of self-concept disorders, such as low self-esteem expressed by feeling embarrassed to meet others, feeling insecure with others, and feeling unworthy when seen by others.

Declining self-concept triggers insecurity and embarrassment when interacting with others (Peters et al., 2016). Embarrassment arises in people with leprosy over changes in physical conditions that cannot be avoided after contracting leprosy (Jezus et al., 2018). Feelings of shame about physical conditions are triggered by feelings of fear of receiving labeling with connotations that are not pleasant to hear (Peters et al., 2015). Decreasing the level of individual confidence is influenced by changes in physical shape so that body image changes negatively. The assessment of a negative body image can also reduce the assessment of oneself in worth as a whole individual. The expression of decreased individual body image is characterized by feelings of shame when interacting with others and low selfconfidence.

The way to overcome psychosocial problems was conveyed by participants by getting social support from people around them, doing spiritual activities, and shifting the focus of mind from stressors. How to deal with stressors positively in people with leprosy is by utilizing social support from others around them (Dako-Gyeke, Asampong and Oduro, 2017). Every leprosy sufferer expressed the importance of getting social support from other people, from family, neighbors, and health workers (Mahardita et al., 2019). Health workers play an important role in the welfare of individuals suffering from the disease (Tristiana et al., 2016). Social support naturally reduces stigma in people affected by leprosy. Social support is also able to improve the recovery of person affected with leprosy by providing emotional support for person affected with leprosy undergoing routine treatment (Saputri \& Luthviatin, 2017). In addition, the relationship with the individual environment also has a relationship with his God.

Spiritual activity is a medium of communication between individuals and their God. Individuals say a prayer as a form of effort in obtaining healing (Arifin et al., 2019). Spiritual activities are carried out individually and 
together to obtain peace, such as accepting gracefully any unexpected conditions, including disability due to leprosy. Spirituality can overcome stress by suppressing negative responses to stressors (Debnam et al., 2016). A good spiritual level in person affected with leprosy can reduce stress indicators, such as emotional changes, behavioral and physical changes (Yadav, Khanna and Singh, 2017) because spirituality teaches individuals to be broad-hearted, steadfast, and calm in the face of problems (Yusuf et al., 2016). Religious activities have two important components that make spirituality able to cope with stress, namely how important your beliefs are for yourself and diverting each problem to belief (Debnam et al., 2016). These two components make spirituality a driving force from current conditions to expected conditions (Yadav, Khanna and Singh, 2017). The current condition of people with leprosy with disabilities is a stressor that burdens the psychological state of individual. In addition to dealing with stressors, individuals can shift their focus of mind by doing many activities.

Diverting the mind's focus from the stressor becomes the right choice by farming while reactivating their work. The calm atmosphere in the rice fields makes person affected with leprosy suffer only from natural stressors. The fresh color components, the cool weather, and the calm atmosphere make the activities of the person affected with leprosy favored as the object of diversion. Stressors in people with leprosy can be overcome in a variety of positive ways. The psychological burden due to stressors can be minimized by gardening activities. Gardening can provide significant benefits to mental health (Quick et al., 2017). It can also improve physical and psychological wellbeing, reduce social isolation, reduce anxiety, and depression (Noone et al., 2017). In addition to improving mental health and physical health, gardening can also improve cognitive function (Chan et al., 2017). In addition to active coping with leprosy, patients are also able to implement positive adaptations.

Adjustment to health conditions with disabilities in people with leprosy is needed to restructure activities that had been abandoned after being diagnosed with leprosy, such as work. Work done actively shows that leprosy sufferers have been able to cope with stress.
Besides being able to work actively, person affected with leprosy can interact socially without obstacles with others around them as a form of adaptation to health conditions. The ability of positive adaptation can be done to help individuals survive, overcome, become strong, even change, and can develop even in difficult circumstances (Mir' atannisa, Intan Mutiara Rusmana, \& Budiman, 2019). Persons affected by leprosy are able to remain actively working despite limitations caused by disabilities due to their illness (Ayu, Mayang Sari, 2020). Work by individuals who have disabilities due to leprosy requires vigilance to maintain work safety (Rismayanti et al., 2017) because the majority of people affected by leprosy actively work as farmers (Widya, Adi and Martini, 2019), in the sense that every individual has the same right for work and decent livelihoods (Dewi and Nim, 2019) and person affected with leprosy are no exception.

Social interaction can improve the psychological wellbeing of person affected with leprosy (Dako-Gyeke, 2018). Social interaction is a natural relationship and interest with the rights of the interaction of each subject (Sun, Cui and $\mathrm{Xu}, 2018$ ). It is a media channeling empathy and communication that can heal mental health (Wiederhold, Riva and Kim, 2019), especially in person affected with leprosy who have physical disabilities and disabilities. For person affected with leprosy who can show respect for themselves, including a healthy mind, self-esteem is shown by confidence in showing maximum ability (Suryani, 2012) so that it has a positive impact on leprosy patients, namely improving the quality of life after experiencing disability due to illness (Nugraheni, 2016) because, in many cases, person affected with leprosy with disabilities have decreased quality of life and feel their life is meaningless (Govindharaj, Srinivasan and Darlong, 2018). In terms of adaptation to leprosy, sufferers discussed various actions in daily activities, such as actively working with their respective professions and being able to facilitate normal activities with others around them.

Characteristics of resilient individuals in leprosy are shown by positive behaviors, such as being more productive in filling daily activities, positive adaptation by being able to accept oneself with all the limitations due to permanent disability after being diagnosed 
with leprosy and being able to assist others and in good coping mechanisms in responding positively to undesirable conditions. Positive thinking is used to change situations that cause stress so as to reduce negative emotions (Hidayah, Yusuf, \& Fitryasari, 2017). For person affected with leprosy with disabilities, being productive is one way of showing that people with disabilities can work as individuals (Maxwell Peprah Opoku, Naomi Gyamfi, Eric Badu, 2018). The ability of individuals who experience adversity to rise and help others shows resilient characteristics (MacLeod et al., 2016). Persons affected by leprosy define helping others as the act of giving back the support given by others by helping others in turn (Alessi, 2016). By helping other people affected by leprosy, they can show selfactualization as whole individuals despite all their limitations. Helping others shows that person affected with leprosy have been able to overcome psychosocial problems experienced with effective coping strategies (First, First and Houston, 2018).

Limitations in this study were not exploring the condition of people affected by leprosy after resilience and ways to maintain their condition and not differentiating participants by sex. However, this research reports the process of leprosy sufferers to become strong individuals a can be used as encouragement and motivation for other person affected with leprosy to achieve resilience.

\section{CONCLUSION}

In this study, the following conclusions are obtained: 1) Stressor in person affected with leprosy with disabilities due to illness is a stigma against themselves in the form of labeling and discrimination and physical disability; 2) Psychosocial problems are shown by person affected with leprosy with disabilities due to illness in the form of anxiety responses, withdrawal from the environment and selfconcept disorders; 3) Active coping done by people affected by leprosy with disabilities due to illness to cope with stress is such as utilizing social support, actively participating in religious activities and shifting the focus of the mind by farming; 4) The positive adaptation shown by person affected with leprosy with disabilities due to their illnesses is actively working within all limitations, carrying out social interactions with others, valuing themselves as whole individuals, and being able to adjust to changes in physical conditions; 5) Characteristics of resilient individuals identified in leprosy patients with disabilities due to illness consist of three components, namely changes in behavior while still living productively, emotional changes by thinking positively under unexpected conditions, and showing the ability to help others.

\section{Acknowledgement}

To all participants for participating in the study.

\section{Conflict of Interest}

None.

\section{REFERENCES}

Alessi, E. J. (2016) 'Resilience in sexual and gender minority forced migrants: A qualitative exploration', Traumatology, 22(3), PP. 203-213. doi: 10.1037/trm0000077.

Arachchi, M. A. J. D. M. et al. (2017) 'Stigmatization in Leprosy: A descriptive study from patients' perspective in Sri Lanka', Scientific Research Journal (SCIRJ), 5(9), pp. 10-13.

Arifin, H. et al. (2019) 'Diabetes Resilience Training on Self-Care, Glycemic Control, and Diabetes Burnout of Adult Type 2 Diabetes Mellitus', Indonesian Nursing Journal of Education and Clinic (INJEC), 4(2), PP. 90-98. doi: http://dx.doi.org// 0.24990/injec.v4i2.252.

Arifin, H., Kusnanto, K. and Widyawati, I. Y. (2020) 'How did I Feel Before Becoming Diabetes Resilience? A Qualitative Study in Adult Type 2 Diabetes Mellitus', Indonesian Nursing Journal of Education and Clinic (INJEC), 5(I), PP. 27-34. doi: http://dx.doi.org// 0.24990/injec.v5il.280.

Ayu, Mayang Sari, H. (2020) 'Dukungan Keluarga Sebagai Caregiver Pada Penderita Kusta Family Support As a Caregiver in Leprosy', Jurnal Kedokteran 
STM, 3(I), Pp. 9-15.

Barakat, M. M. and Zaki, N. (2020) 'Relationship between Psychological Problems and Quality of Life among Leprosy Patients', (January). doi: I0.13 I 40/RG.2.2.27279.74404.

Borges, I. C. C. and Machado, C. J. (2019) 'Castro M. A praga: o holocausto da hanseníase. Histórias emocionantes de isolamento, morte e vida nos leprosários do Brasil. São Paulo: Geração Editorial; 2017.', Ciência \& Saúde Coletiva, 24(4), PP. |57|-1572. doi: 10.1590/14|3$8 \mid 232018244.14512018$.

Chan, H. Y. et al. (2017) 'Effects of horticultural therapy on elderly' health: Protocol of a randomized controlled trial', BMC Geriatrics. BMC Geriatrics, I7(I), pP. I-10. doi: 10.1 I86/s | 2877-0I7-0588-z.

Dadun, D. et al. (2017) 'Impact of socioeconomic development, contact and peer counselling on stigma against persons affected by leprosy in Cirebon, Indonesia - a randomised controlled trial', Leprosy Review, 88(I), Pp. 2-22.

Dako-Gyeke, M. (20I8) 'Courtesy stigma: A concealed consternation among caregivers of people affected by leprosy', Social Science and Medicine, 196(October), PP. 190-196. doi: 10.1016/j.socscimed.2017.11.030.

Dako-Gyeke, M., Asampong, E. and Oduro, R. (2017) 'Stigmatisation and discrimination: Experiences of people affected by leprosy in Southern Ghana', Leprosy Review, 88(I), Pp. 58-74.

Debnam, K. et al. (2016) 'The Role of Stress and Spirituality in Adolescent Substance Use', Substance Use and Misuse. Taylor \& Francis, 5I(6), PP. 733-74I. doi: I0.3109/10826084.2016.II55224.

Dewi, A. C. and Nim, M. (2019) 'Strategi Pemerintah dalam Pemerataan Pekerjaan bagi Penyandang Disabilitas di Kota Surakarta'.

Farah Naaz et al. (2017) 'Challenges Beyond Elimination in Leprosy', International Journal of Mycobacteriology, 6(3), Pp. 239245. doi: 10.4103/ijmy.ijmy.

First, J., First, N. L. and Houston, J. B. (2018) 'Resilience and Coping Intervention ( $\mathrm{RCl})$ : A Group Intervention to Foster College Student Resilience', Social Work with Groups. Routledge, 4I(3), Pp. 198-2I0. doi: I0.1080/0I6095|3.20I6.1272032.

George, M. R. (2016) 'Effectiveness of Bibliotherapy on Stress among Patients with Hansen 's Disease Ancheril Nursing', Internatioanl Journal of Scientific Research, 5(I0), pp. 5-6.

Govindharaj, P., Srinivasan, S. and Darlong, J. (2018) 'Quality of Life of People Affected with Leprosy Disability Living in Purulia , International Journal of Health Sciences and Research Quality of Life of People Affected with Leprosy Disability Living in', 8(February), pp. 22I-225.

Groot, R. De, Brakel, W. H. Van and Vries De, H. J. C. (2020) 'Social implications of leprosy in the Netherlands - stigma among ex-leprosy patients in a non-endemic setting'.

Grzybowski, A. et al. (2016) 'Leprosy: Social implications from antiquity to the present', Clinics in Dermatology, 34(I), PP. $8-10$. doi: 10.1016/j.clindermatol.2015.10.009.

Hendriani, wiwin (2018) resiliensi psikologis sebuah pengantar. satu. Jakarta: Prenadamedia Group.

Hendriani, W. (2016) 'Pengembangan Modul Intervensi untuk Meningkatkan Resiliensi pada Individu yang Mengalami Perubahan Fisik Menjadi Penyandang Disabilitas', INSAN Jurnal Psikologi dan Kesehatan Mental, I(I), P. 66. doi: I0.20473/jpkm.vlil 20I6.66-75.

infodatin (2018) 'hapuskan stigma dan diskriminasi terhadap kusta', p. 4.

Jezus, S. V et al. (2018) 'Assessment of patients 'perceptions towards the diagnosis of leprosy', I I(Id), PP. I07-II5.

Kementrian Kesehatan RI (2018) 'profil kesehatan indonesia tahun 2017', p. 220.

Lestari, R. and Yusuf, A. (2017) 'Community Resilience as a Recovery Method for Psychiatric Patients: A Meta-Study', (January). doi: I0.5220/00075|400344035I.

Local Health Office of Sumenep Regency (2017) 'Profil Kesehatan Kabupaten Sumenep Tahun 2017', p. 37.

Lusli, M. et al. (20I5) 'Dealing with stigma: Experiences of persons affected by disabilities and leprosy', BioMed Research International, 2015. doi: $10.1155 / 2015 / 261329$.

MacLeod, S. et al. (2016) 'The impact of 
resilience among older adults', Geriatric Nursing. Elsevier Inc, 37(4), pp. 266-272. doi: 10.1016/j.gerinurse.2016.02.014.

Mahardita, N. G. P. et al. (2019) 'Prevalence of Disability and Drop out from Treatment: A Cross-sectional Study of Social Stigma and Motivation for Healing Among People Affected by Leprosy in District of Jember , East Java Province , Indonesia', Pp. 243256.

Marfatia, Y. S., Surani, A. and Shah, D. (2020) 'Delay in leprosy diagnosis', Indian Journal of Leprosy, 92, pp. 19-29.

Maxwell Peprah Opoku, Naomi Gyamfi, Eric Badu, W. K. M. (20I8) "'They think we are all beggars": The resilience of a person with disability in Ghana', Journal of Exceptional People 2018 -, I(I2).

Mir'atannisa, Intan Mutiara Rusmana, N. and Budiman, N. (2019) 'Kemampuan Adaptasi Positif Melalui Resiliensi', Journal of Innovative Counseling: Theory, Practice \& Research, 3(2), pp. 70-76.

Nardi Assis, B. P. et al. (20/9) 'Risk factors for physical disability upon release from multidrug therapy in new cases of leprosy at a referral center in Brazil', Revista do Instituto de Medicina Tropical de Sao Paulo, 6I(November 2018), PP. I-9. doi: 10.1590/s 1678-99462019610I3.

Nasrudin et al. (2018) 'The Analysis of Influences of Family Stress Factors with $A B C X$ Theory on Family with Leprosy in Jombang Regency, East Java , Indonesia', The 2nd Joint International Conferences, 29, Pp. 264-270.

Noone, S. et al. (2017) "'The nourishing soil of the soul": The role of horticultural therapy in promoting well-being in community-dwelling people with dementia', Dementia, 16(7), pp. 897-910. doi: $10.1177 / 147 \mid 301215623889$.

Nugraheni, R. (2016) 'Analisis Konsep Diri Terhadap Kualitas Hidup Penderita Kusta Yang Mengalami Kecacatan Di Rumah Sakit Kusta Kediri', Preventia: The Indonesian Journal of Public Health, I(2), p. 164. doi: 10.17977/um044v|i2pl64-173.

Peters, R. M. H. et al. (20I5) 'A ClusterRandomized Controlled Intervention Study to Assess the Effect of a Contact Intervention in Reducing Leprosy-Related Stigma in Indonesia', PLoS Neglected Tropical Diseases, 9(10), Pp. I-24. doi: 10.137|/journal.pntd.0004003.

Peters, R. M. H. et al. (2016) "'People like me don't make things like that": Participatory video as a method for reducing leprosyrelated stigma', Global Public Health. Taylor \& Francis, II(5-6), Pp. 666-682. doi: $10.1080 / 17441692.2016 .1153122$.

Quick, J. S. et al. (2017) 'Vegetable garden as therapeutic horticulture for patients with chronic pain', Pain Medicine (United States), I8(II), PP. 2252-2254. doi: 10.1093/pm/pnx065.

Rahmawati, R., Nafiah, H. and Hidayati R, R. (20I5) 'Coping Mechanism of Leprae Patient', Jurnal IImiah Kesehatan (IIK), VII(I).

Ramasamy, S. et al. (2018) 'Progressive muscle relaxation technique on anxiety and depression among persons affected by leprosy', I4(3), Pp. 375-38I.

Richardus, R. et al. (2018) 'BCG and adverse events in the context of leprosy', Frontiers in Immunology, 9(APR), PP. I-II. doi: I0.3389/fimmu.2018.00629.

Rismayanti, R. et al. (2017) 'Faktor Risiko Kejadian Kecacatan Tingkat 2 Pada Penderita Kusta', Media Kesehatan Masyarakat Indonesia, I3(I), p. 5I. doi: 10.30597/mkmi.vl3il.I58I.

Saputri, Y. P., Luthviatin, N. and Kependudukan, B. (2017) 'Hubungan antara Dukungan Sosial Keluarga dengan Kepatuhan Minum Obat Penderita Kusta (Studi di Kecamatan Puger dan Balung Kabupaten Jember) The Relationship between Family Social Support with Medicine Compliance of Leprosy Patients (Study in Puger and Bal', e-Jurnal Pustaka Kesehatan, 5(3), pp. 549-556.

Siddiqi, M., Chattopadhyay, P. and Ghosh, P. (2017) 'Adaptation of scales assessing perceived and internalized stigma, selfesteem and social participation of leprosy affected persons in colloquial Bengali language', 3(I), Pp. 29I-295.

Smith, B. W. et al. (2008) 'The brief resilience scale: Assessing the ability to bounce back', International Journal of Behavioral Medicine, 15(3), PP. 194-200. doi: I0.1080/I 0705500802222972.

Sniatecki, J. L. et al. (2019) 'Positive aspects of disability among college students', Journal of Research in Innovative Teaching \& Learning, ahead-of-p(ahead-of-print). doi: 10.1 I08/jrit-09-2019-0069. 
Sodik, M. A. (2016) 'Vol. I No. 2 Juli-Desember 2016 ISSN 528-066X', I(2), pp. 99-106.

Southwick, S. M. et al. (2016) 'Why are some individuals more resilient than others: the role of social support', World Psychiatry, I5(I), pp. 75-77. doi: 10.1002/wps.20280.

Srinivas, G. et al. (2019) 'Risk of disability among adult leprosy cases and determinants of delay in diagnosis in five states of India: A case-control study', PLoS Neglected Tropical Diseases, 13(6), Pp. I15. doi: 10.1371/journal.pntd.0007495.

Sun, W. B., Cui, H. W. and Xu, C. Q. (2018) 'Innovative mode of integrated development of higher vocational education based on social interaction theory', Kuram ve Uygulamada Egitim Bilimleri, 18(6), pP. 3043-305।. doi: I0.12738/estp.2018.6.204.

Suryani, S. fajar (20I2) 'Inferioritas Dan Kepercayaan Diri Pada Penyandang Tuna Rungu', 66, pp. 37-39.

Tristiana, R. D. et al. (2016) 'Psychological Well Being In Type 2 Diabetes Mellitus Patients In Mulyorejo Public Health Center Surabaya', Jurnal NERS, I I(2), p. I47. doi: I0.20473/jn.v I Ii220I6.147-I56.

Utami, C. T. (2017) 'Self-Efficacy dan Resiliensi: Sebuah Tinjauan Meta-Analisis', Buletin Psikologi, 25(I), PP. 54-65. doi: 10.22 |46/buletinpsikologi. I84I9.

Utami, R., Haryanto, J. and Sajidin, M. (2017) 'Path analysis of the factors that influence the prevention of leprosy clients depression in leprosy hospital Sumberglagah Mojokerto, East Java, Indonesia', International journal of science and research, 6(6), Pp. 43I-435. doi:
I0.2I275/ART20I74228.

Widya, T. N., Adi, M. S. and Martini (2019) 'Gambaran Faktor Risiko Kecacatan Pada Penderita Kusta', Jurnal Kesehatan Masyarakat (e-Journal), 7(3), pp. 54-59.

Wiederhold, B. K., Riva, G. and Kim, S. I. (2019) Annual Review of Cybertherapy and Telemedicine 2010. Introduction., Studies in health technology and informatics.

Williams, A. et al. (2019) 'Study of clinical spectrum and factors associated with disabilities in leprosy: A ten year retrospective analysis', Indian Journal of Leprosy, 9I, pp. 37-45.

Yadav, R., Khanna, A. and Singh, D. (2017) 'Exploration of Relationship Between Stress and Spirituality Characteristics of Male and Female Engineering Students: A Comprehensive Study', Journal of Religion and Health, 56(2), Pp. 388-399. doi: 10.1007/s 10943-015-0174-7.

Yusuf, A. et al. (2009) 'Riset Kualitatif Dalam Keperawatan', Universitas Gunadarma, pp. I-4.

Yusuf, A. et al. (2016) 'Kebutuhan Spiritual Konsep Dan Aplikasi Dalam Keperawatan', penerbit Mitra Wacana Media. doi: 10.1002/nml. II308.

Yusuf, A., Suarilah, I. and Rahmat, P. (2010) 'Relaxation Affi rmation Technique Increases Self Effi cacy of Patients with Nasopharingeal Cancer', Jurnal Ners, 5(I), pp. 29-37.

Zamparoni, V. (2017) 'Leprosy: Disease, isolation, and segregation in colonial Mozambique', Historia, Ciencias, Saude Manguinhos, 24(I), PP. I-27. doi: I0.1590/S0I04-59702016005000028. 